\title{
Bacterial Growth in Chloride and Perchlorate Brines: Halotolerances and Salt Stress Responses of Planococcus halocryophilus
}

\author{
Jacob Heinz, ${ }^{1}$ Annemiek C. Waajen, ${ }^{1,2}$ Alessandro Airo,, Armando Alibrandi, \\ Janosch Schirmack, and Dirk Schulze-Makuch ${ }^{1,3,4,5}$
}

\begin{abstract}
Extraterrestrial environments encompass physicochemical conditions and habitats that are unknown on Earth, such as perchlorate-rich brines that can be at least temporarily stable on the martian surface. To better understand the potential for life in these cold briny environments, we determined the maximum salt concentrations suitable for growth (MSCg) of six different chloride and perchlorate salts at $25^{\circ} \mathrm{C}$ and $4{ }^{\circ} \mathrm{C}$ for the extremotolerant cold- and saltadapted bacterial strain Planococcus halocryophilus. Growth was measured through colony-forming unit (CFU) counts, while cellular and colonial phenotypic stress responses were observed through visible light, fluorescence, and scanning electron microscopy. Our data show the following: (1) The tolerance to high salt concentrations can be increased through a stepwise inoculation toward higher concentrations. (2) Ion-specific factors are more relevant for the growth limitation of $P$. halocryophilus in saline solutions than single physicochemical parameters like ionic strength or water activity. (3) P. halocryophilus shows the highest microbial sodium perchlorate tolerance described so far. However, (4) MSCg values are higher for all chlorides compared to perchlorates. (5) The MSCg for calcium chloride was increased by lowering the temperature from $25^{\circ} \mathrm{C}$ to $4^{\circ} \mathrm{C}$, while sodium- and magnesium-containing salts can be tolerated at $25^{\circ} \mathrm{C}$ to higher concentrations than at $4^{\circ} \mathrm{C}$. (6) Depending on salt type and concentration, $P$. halocryophilus cells show distinct phenotypic stress responses such as novel types of colony morphology on agar plates and biofilm-like cell clustering, encrustation, and development of intercellular nanofilaments. This study, taken in context with previous work on the survival of extremophiles in Mars-like environments, suggests that highconcentrated perchlorate brines on Mars might not be habitable to any present organism on Earth, but extremophilic microorganisms might be able to evolve thriving in such environments. Key Words: Brines-Salt—GrowthMars-Perchlorate-Halotolerance. Astrobiology 19, 1377-1387.
\end{abstract}

\section{Introduction}

M OST SUBZERO SALINE HABITATS on Earth are dominated by sodium chloride $(\mathrm{NaCl})$, and most research has been focused on this salt (for review, e.g., Gunde-Cimerman et al., 2018). However, non- $\mathrm{NaCl}$ saline environments exist on Earth as well, such as the calcium chloride-rich Don Juan Pond, Antarctica (Dickson et al., 2013) or the Spotted Lake, Canada, having high sulfate concentrations (Pontefract et al., 2017).
Similarly, soils on Mars contain non- $\mathrm{NaCl}$ salts such as perchlorates (Hecht et al., 2009). Accordingly, the presence of perchlorate-rich martian groundwater has been discussed (Clifford et al., 2010). Fitting well to this hypothesis, it was recently proposed that a discovered subsurface lake might contain magnesium and calcium perchlorates causing a freezing point depression of water down to its calculated temperature of $-68^{\circ} \mathrm{C}$ (Orosei et al., 2018). Furthermore, spectral investigations indicated that perchlorate salt hydrates and their brines might play a role

\footnotetext{
${ }^{1}$ Center of Astronomy and Astrophysics, Astrobiology Research Group, Technical University of Berlin, Berlin, Germany.

${ }^{2}$ UK Centre for Astrobiology, School of Physics and Astronomy, University of Edinburgh, Edinburgh, UK.

${ }^{3}$ School of the Environment, Washington State University, Pullman, Washington, USA.

${ }^{4}$ GFZ German Center for Geoscience, Section Geomicrobiology, Potsdam, Germany.

${ }^{5}$ Leibniz-Institute of Freshwater Ecology and Inland Fisheries (IGB), Department of Experimental Limnology, Stechlin, Germany.

(C) Jacob Heinz et al., 2019; Published by Mary Ann Liebert, Inc. This Open Access article is distributed under the terms of the Creative Commons Attribution Noncommercial License (http://creativecommons.org/licenses/by-nc/4.0/) which permits any noncommercial use, distribution, and reproduction in any medium, provided the original author(s) and the source are credited.
} 
in the formation of recurring slope lineae (RSL) on Mars (Ojha et al., 2015).

At the Phoenix landing site, perchlorate concentrations in the martian soil are ranging from 0.4 to $0.6 \mathrm{wt} \%$ (Hecht et al., 2009). However, it has to be kept in mind that the perchlorates are present as solid salts which will form highly concentrated brines whenever the temperature is above the eutectic temperature and the relative humidity ( $\mathrm{RH})$ is above the deliquescence relative humidity (DRH) of the perchlorate salt (Davila et al., 2010; Nikolakakos and Whiteway, 2015; Heinz et al., 2016). For example, at $-34^{\circ} \mathrm{C}$ the sodium perchlorate concentration of the forming eutectic brine would be $52.6 \mathrm{wt} \%$ (9M) (Hennings et al., 2013), which is too high for any organism we know from Earth to thrive therein. Therefore, only diluted perchlorate brines might serve as a habitat. These diluted solutions could be stable in the subsurface of Mars (Burt, 2003; Martínez and Renno, 2013).

Since there are diurnal and seasonal temperature and humidity changes on Mars, it can be assumed that salt concentrations in these brines also fluctuate due to crystallization of ice or salt hydrates at cold temperature conditions or due to water absorption from the atmosphere at high $\mathrm{RH}$ conditions, for example in the morning hours when the $\mathrm{RH}$ in the martian atmosphere is highest and can reach saturation (Harri et al., 2014). Thus, microorganisms would have to survive temporarily enhanced salt concentrations (including crystallization processes) at low temperatures and thrive at times of higher temperatures and brine dilution. It has already been shown that low temperatures enhance the bacterial survival in chloride $\left(\mathrm{Cl}^{-}\right)$and perchlorate $\left(\mathrm{ClO}_{4}^{-}\right)$ brines with eutectic concentrations while, additionally, the high salt concentrations benefit the survival during freeze/ thaw cycles of the brine (Heinz et al., 2018). However, the question how low the salt concentration would have to be for microbial growth remained open prior to this study.

The exploration of the physicochemical limits for growth and survival of organisms thriving in cold saline environments gives not only insight into the microbial ecosystems adapted to the most extreme habitats on Earth but also provides the necessary data for assessing the habitability of extraterrestrial environments, for example on Mars (Schulze-Makuch et al., 2015, 2017). A model organism for halo- and psychrotolerant bacteria is Planococcus halocryophilus, which has been isolated from the active layer of permafrost soil in the Canadian High Arctic (Mykytczuk et al., 2012). It is able to grow at $19 \mathrm{wt} / \mathrm{vol} \% \mathrm{NaCl}$ (corresponding to $16 \mathrm{wt} / \mathrm{wt} \%$ ) concentration and at $-15^{\circ} \mathrm{C}$, while showing metabolic activity down to $-25^{\circ} \mathrm{C}$ (Mykytczuk et al., 2013; Raymond-Bouchard et al., 2017).

Bacterial growth of $P$. halocryophilus under these harsh conditions is enabled by the expression of various osmolyte transporters and cold-adapted proteins, a high lipid turnover rate, and a high resource efficiency at subzero temperatures with an accumulation of carbohydrates as energy resource (Mykytczuk et al., 2013). Furthermore, analyses of the proteome of $P$. halocryophilus revealed intricate changes in protein expression (Raymond-Bouchard et al., 2017). Under subzero growth conditions, this bacterial strain develops a nodular sheet-like crust around the cells which might provide protection against cold and osmotic stress (Ronholm et al., 2015; Mykytczuk et al., 2016).

The ability to tolerate these cold and salty conditions was the reason for choosing $P$. halocryophilus as a suitable an- alog microorganism to test how well microbes on Earth can adapt to the conditions prevailing on Mars and whether adaption to high-concentration perchlorate brines is possible with the available biochemical toolset of life as we know it. $P$. halocryophilus is an aerobic organism and thus, at first glance, might not appear relevant to martian habitability, given that the molecular oxygen $\left(\mathrm{O}_{2}\right)$ content in the martian atmosphere is very low $(0.13 \%)$. However, recent studies found that martian brines can be enriched with dissolved $\mathrm{O}_{2}$ up to $2 \mathrm{~mol} \mathrm{~m}^{-3}$, enabling aerobic microbes to metabolize (Stamenković et al., 2018). In addition, there might be other suitable extraterrestrial habitats that provide both osmotic stress conditions and feasible $\mathrm{O}_{2}$ levels.

Here, we investigated the maximum halotolerance for growth of $P$. halocryophilus at optimal growth temperature $\left(25^{\circ} \mathrm{C}\right)$ and low temperature $\left(4^{\circ} \mathrm{C}\right)$ for various $\mathrm{Cl}^{-}$and $\mathrm{ClO}_{4}{ }^{-}$ salts. Furthermore, we investigated the phenotypic adaptations to salt stress such as changes in cell and colony morphology and the formation of cell clusters. This study examines several major aspects important for astrobiological research especially on Mars where $\mathrm{Cl}^{-}$and $\mathrm{ClO}_{4}{ }^{-}$ brines might be the last possible refuges for life (Davila and Schulze-Makuch, 2016).

\section{Materials and Methods}

\subsection{Organism and culture conditions}

The bacterial strain Planococcus halocryophilus Or1 (DSM $24743^{\mathrm{T}}$ ), obtained from the DSMZ (Leibniz Institute DSMZ-German Collection of Microorganisms and Cell Cultures) was used in all experiments described within this study. The bacteria were grown aerobically at $25^{\circ} \mathrm{C}$ (optimum growth temperature) or $4^{\circ} \mathrm{C}$ (low temperature control) in liquid DSMZ growth medium \#92 (3\% Tryptic soy broth [TSB], $0.3 \%$ yeast extract) with various concentrations (1 wt $\%$ [w/w] incremental steps) of one of the following salts: sodium chloride $(\mathrm{NaCl})$, magnesium chloride $\left(\mathrm{MgCl}_{2}\right)$, calcium chloride $\left(\mathrm{CaCl}_{2}\right)$, sodium perchlorate $\left(\mathrm{NaClO}_{4}\right)$, magnesium perchlorate $\left(\mathrm{Mg}\left(\mathrm{ClO}_{4}\right)_{2}\right)$, or calcium perchlorate $\left(\mathrm{Ca}\left(\mathrm{ClO}_{4}\right)_{2}\right)$. The media were prepared by mixing the media components, salt and water, followed by $\mathrm{pH}$ adjustment $(\mathrm{pH}$ 7.2-7.4), centrifugation if necessary (in calcium-containing samples, yeast flocculation can occur [Stratford, 1989] which has no influence on the cells' growth, because $P$. halocryophilus readily thrives in medium containing only TSB [Mykytczuk et al., 2012]), and sterile filtration.

\subsection{Determination of the maximum salt concentration suitable for growth (MSCg)}

Bacteria were monitored for growth and death by using colony-forming unit (CFU) counts to determine the MSCg values of the respective salts. Two identical samples were prepared and inoculated separately (biological duplicates) for each experiment. For CFU counts, two aliquots of $100 \mu \mathrm{L}$ were taken from each sample and plated on agar plates containing DSMZ growth medium \#92. CFUs for the same experimental conditions were averaged by using the arithmetic mean. Where necessary, the aliquots were diluted with phosphate-buffered saline (PBS) containing additional $10 \mathrm{wt} \% \mathrm{NaCl}$ (for all sodium-containing samples) or $10 \mathrm{wt} \%$ $\mathrm{MgCl}_{2}$ (for all magnesium- or calcium-containing samples). 
The increased amount of salt in the PBS was necessary to avoid bursting of cells by osmotic pressure during the dilution of the saline growth media. Some experiments were repeated to check reproducibility.

To investigate the effect of the inoculation culture on growth and survival of $P$. halocryophilus in the salty samples, $5 \mathrm{~mL}$ of the saline medium was inoculated with one of the following inoculation methods (IMs):

- IM 1: The medium was inoculated with the stock culture (growth medium $+10 \mathrm{wt} \% \mathrm{NaCl}$ ) at $25^{\circ} \mathrm{C}$.

- IM 2: The medium was inoculated with a culture grown at the respective temperature $\left(25^{\circ} \mathrm{C}\right.$ or $\left.4^{\circ} \mathrm{C}\right)$ in medium with lower concentration of the respective salt (progressive culture adaption).

- IM 3: Medium for experiments at $25^{\circ} \mathrm{C}$ was inoculated with a culture grown at $4^{\circ} \mathrm{C}$ in medium with the same or higher concentration of the respective salt.

- IM 4: Medium for experiments at $4^{\circ} \mathrm{C}$ was inoculated with a culture grown at $25^{\circ} \mathrm{C}$ in medium with the same or higher concentration of the respective salt.

Inoculation volumes ranged from 10 to $50 \mu \mathrm{L}$ depending on the cell density of the inoculation culture. However, due to cell clustering (Section 3.2.2) the starting cell density after inoculation varied between $5 \cdot 10^{2} \mathrm{CFU} / \mathrm{mL}$ and $5 \cdot 10^{4} \mathrm{CFU} / \mathrm{mL}$.

Because progressive culture adaptions were done by a $1 \mathrm{wt} \%$ stepwise increase in the salt concentrations of the medium, the MSCg values had an inherent uncertainty of $1 \%$. Larger uncertainties (up to $2 \%$ ) occurred for some samples incubated at $4^{\circ} \mathrm{C}$ when cells in media with salt concentrations above the MSCg neither grew nor died within the time of the experiment.

\subsection{Light, fluorescence, and scanning electron microscopy}

A set of samples was investigated under the light microscope (Primo Star, Zeiss, equipped with Axio Cam 105 color) without prior sample treatment. For fluorescence microscopy of living and dead cells, samples were washed twice with PBS containing $10 \mathrm{wt} \% \mathrm{NaCl}$. Three milliliters of each sample was stained with $3 \mu \mathrm{L}$ of a 1:2 mixture of component A (SYTO 9 dye, $3.34 \mathrm{mM}$ ) and component B (propidium iodide, $20 \mathrm{mM}$ ) from the Invitrogen Live/Dead BacLight Bacterial Viability Kit, where component A causes green fluorescence of intact cells and component B causes red or orange fluorescence of dead cells with damaged cell walls. The stained samples were imaged with a fluorescence microscope (Polyvar 2, Reichert-Jung) equipped with a Xenon lamp (XBO $150 \mathrm{~W} / 1$ ).

Samples for scanning electron microscopy (SEM) were washed twice with PBS containing $10 \mathrm{wt} \% \mathrm{NaCl}$ followed by fixation in $2.5 \%$ glutaraldehyde solution (in $0.1 \mathrm{M}$ phosphate buffer $[\mathrm{PB}], \mathrm{pH}=7.3$ ). The fixed samples were washed twice with $0.1 \mathrm{M} \mathrm{PB}$, dehydrated through a graded acetone series $(50 \%, 70 \%, 90 \%, 95 \%, 100 \%)$, critical point dried in a Leica CPD300, coated with carbon, and imaged with a Hitachi S-2700 microscope.

\section{Results}

\subsection{Growth at $25^{\circ} \mathrm{C}$ and $4^{\circ} \mathrm{C}$}

3.1.1. Growth curves and $\mathrm{MSCg}$ values. For determining the MSCg values of all $\mathrm{Cl}^{-}$and $\mathrm{ClO}_{4}^{-}$salts, we used growth versus death as a distinction criterion. For example, after 6 days of incubation in $\mathrm{CaCl}_{2}$-rich media, $P$. halocryophilus shows an increase in $\mathrm{CFU}$ values (i.e., growth) at $25^{\circ} \mathrm{C}$ under all tested salt concentrations with the exception of $9 \mathrm{wt} \%$; hence at this temperature the $\mathrm{MSCg}$ value is $8 \mathrm{wt} \%$ (Fig. 1). However, at $4^{\circ} \mathrm{C}$ the MSCg value is greater with $10 \mathrm{wt} \%$ (embedded plot of Fig. 1).

All growth curves generated are provided in the Supplementary Materials (Fig. S1-S12, available online at www .liebertonline.com/ast). The resulting MSCg values for all salts and temperatures, including their corresponding total ion concentrations (sum of cation and anion concentration), anion concentrations, ionic strengths, and water activities are listed in Table 1. The MSCg (wt\%), total molar ion concentrations, and anion concentrations are plotted as bar charts in Fig. 2.

Overall, $P$. halocryophilus shows high halotolerances to all $\mathrm{Cl}^{-}$and $\mathrm{ClO}_{4}^{-}$salts at both $25^{\circ} \mathrm{C}$ and $4^{\circ} \mathrm{C}$ (Fig. 2A, 2B). The $\mathrm{Cl}^{-}$tolerance is at least 2.5-fold higher than the tolerance to $\mathrm{ClO}_{4}{ }^{-}$in media with the same cation (Fig. 2C). However, with $12 \mathrm{wt} \%(1.1 \mathrm{M}) \mathrm{NaClO}_{4}$ at $25^{\circ} \mathrm{C}$ we found the highest microbial tolerance to $\mathrm{NaClO}_{4}$ described so far. The lowest tolerated water activity was 0.90 in $14 \mathrm{wt} \%(2.8 \mathrm{M}) \mathrm{NaCl}$, while the highest tolerable ionic strength $(3.9 \mathrm{~mol} / \mathrm{L})$ was reached in $11 \mathrm{wt} \%(1.3 \mathrm{M}) \mathrm{MgCl}_{2}$ at $25^{\circ} \mathrm{C}$ (Table 1).

3.1.2. Effect of the inoculation method (IM) on the MSCg. The applied IM effects the growth curves and the resulting $\mathrm{MSCg}$ values in the following ways:

(1) At $25^{\circ} \mathrm{C}$, the MSCg values could only be reached with IM 2 (progressive culture adaptation at $25^{\circ} \mathrm{C}$ ) but not with IM 1 (inoculation with stock culture) where cell death occurs already at lower salt concentrations. For example, the MSCg for $\mathrm{MgCl}_{2}$ was $9 \mathrm{wt} \%$ at $25^{\circ} \mathrm{C}$ when the media was inoculated with the stock culture (IM 1); however, a stepwise (1 wt\%) increase in the $\mathrm{MgCl}_{2}$ concentration (IM 2) resulted in a $\mathrm{MSCg}$ of $11 \mathrm{wt} \% \mathrm{MgCl}_{2}$ (Fig. S3). It is notable that the length of the growth curve lag phase (occasionally including an initial CFU reduction) is enhanced with increasing salt concentration and decreasing temperatures (e.g., Figs. 1 and S1).

(2) Applying IM $3\left(4^{\circ} \mathrm{C} \rightarrow 25^{\circ} \mathrm{C}\right.$ inoculation) resulted in an increase of the MSCg values at $25^{\circ} \mathrm{C}$ only in the case of $\mathrm{Ca}\left(\mathrm{ClO}_{4}\right)_{2}$ samples. Here, growth in $3 \mathrm{wt} \% \mathrm{Ca}\left(\mathrm{ClO}_{4}\right)_{2}$ was not detected after inoculation with the stock solution (IM 1) nor with a $2 \mathrm{wt} \% \mathrm{Ca}\left(\mathrm{ClO}_{4}\right)_{2}$ culture grown at $25^{\circ} \mathrm{C}$ (IM 2), but only after inoculation with a $3 \mathrm{wt} \% \mathrm{Ca}\left(\mathrm{ClO}_{4}\right)_{2}$ culture grown at $4^{\circ} \mathrm{C}$ (IM 3 ) (Fig. S11).

(3) At $4^{\circ} \mathrm{C}$, a higher MSCg value was reached by applying IM 2 (progressive culture adaptation at $4^{\circ} \mathrm{C}$ ) than by applying IM $4\left(25^{\circ} \mathrm{C} \rightarrow 4^{\circ} \mathrm{C}\right.$ inoculation). For example, at $4^{\circ} \mathrm{C}$ inoculation of $2 \mathrm{wt} \% \mathrm{Mg}\left(\mathrm{ClO}_{4}\right)_{2}$ medium with a $5 \mathrm{wt} \% \mathrm{Mg}\left(\mathrm{ClO}_{4}\right)_{2}$ culture grown at $25^{\circ} \mathrm{C}$ did not show growth, indicating a MSCg $<2 \mathrm{wt} \% \mathrm{Mg}\left(\mathrm{ClO}_{4}\right)_{2}$ when IM 4 is applied. However, a $1 \mathrm{wt} \%$ stepwise increase in $\mathrm{Mg}\left(\mathrm{ClO}_{4}\right)_{2}$ concentration at $4^{\circ} \mathrm{C}$ resulted in an culture able to growth at $4 \mathrm{wt} \%$ $\mathrm{Mg}\left(\mathrm{ClO}_{4}\right)_{2}$ (Fig. S10). These data suggest that for growth at $4^{\circ} \mathrm{C}$ an adaption to the cold first has to take place before $P$. halocryophilus can adapt stepwise to higher salt concentrations at that temperature. 


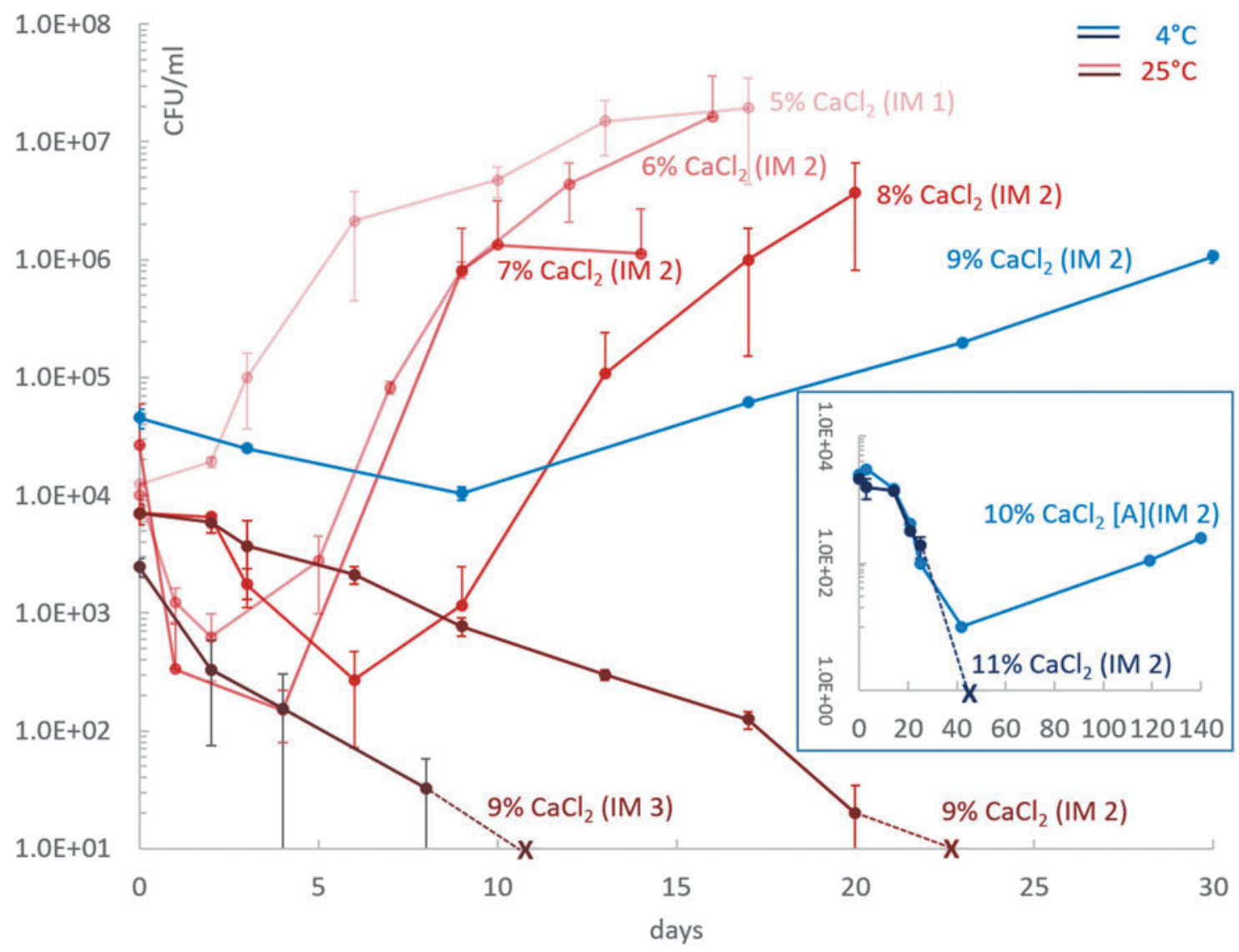

FIG. 1. Growth curves of $P$. halocryophilus in liquid growth media with different $\mathrm{CaCl}_{2}$ concentrations at $25^{\circ} \mathrm{C}$ (red curves) and $4^{\circ} \mathrm{C}$ (blue curves). X indicates the detection limit (no detectable CFUs in a $100 \mu \mathrm{L}$ aliquot). IM describes the inoculation method as explained in Section 2.2. MSCg values are 8 and $10 \mathrm{wt} \% \mathrm{CaCl}_{2}$ for $25^{\circ} \mathrm{C}$ and $4^{\circ} \mathrm{C}$, respectively. Growth in $10 \mathrm{wt} \%$ $\mathrm{CaCl}_{2}$ at $4^{\circ} \mathrm{C}$ (embedded plot) was only observed for one of the two biological duplicates, thus, lacking an error bar.

3.1.3. Temperature effect on the MSCg. The relative shift in the MSCg that occurs by lowering the incubation temperature from $25^{\circ} \mathrm{C}$ to $4^{\circ} \mathrm{C}$ is visualized in Fig. 3 . Among all six salts investigated in this study, only cells in $\mathrm{CaCl}_{2}$-containing media show an enhanced salt tolerance at lower temperature, where growth at 9 and $10 \mathrm{wt} \% \mathrm{CaCl}_{2}$ did not occur at $25^{\circ} \mathrm{C}$ but only at $4^{\circ} \mathrm{C}$ (Fig. 1 ).
Nevertheless, the observation that only IM $4\left(4^{\circ} \mathrm{C} \rightarrow\right.$ $25^{\circ} \mathrm{C}$ inoculation) resulted in growth at the $\mathrm{MSCg}$ for $\mathrm{Ca}\left(\mathrm{ClO}_{4}\right)_{2}(3 \mathrm{wt} \%)$ at $25^{\circ} \mathrm{C}$ (see point (2) of Section 3.1.2) provides evidence that also the tolerance to $\mathrm{Ca}\left(\mathrm{ClO}_{4}\right)_{2}$ is increased at $4^{\circ} \mathrm{C}$, however, to a lower extent than the $1 \mathrm{wt} \%$ salt concentration incremental steps used in this study (Section 2.1). This suggests a general increase in the

Table 1. MSCg Values and Corresponding Total Ion Concentrations (Sum of Cations and Anions), Anion Concentrations, Ionic Strengths, and Water Activities at $25^{\circ} \mathrm{C}$ and $4^{\circ} \mathrm{C}$

\begin{tabular}{|c|c|c|c|c|c|c|c|c|c|c|c|c|}
\hline & \multicolumn{4}{|c|}{$M S C g$} & \multirow{2}{*}{\multicolumn{2}{|c|}{$\frac{\text { Total ion conc. }}{[\mathrm{mol} / \mathrm{L}]}$}} & \multirow{2}{*}{\multicolumn{2}{|c|}{$\frac{\text { Anion conc. }}{[\mathrm{mol} / \mathrm{L}]}$}} & \multirow{2}{*}{\multicolumn{2}{|c|}{$\begin{array}{c}\text { Ionic strength } \\
{[\mathrm{mol} / \mathrm{L}]}\end{array}$}} & \multirow{2}{*}{\multicolumn{2}{|c|}{ Water activity }} \\
\hline & \multicolumn{2}{|c|}{ [wt\%] } & \multicolumn{2}{|c|}{$[\mathrm{mol} / \mathrm{L}]$} & & & & & & & & \\
\hline & $25^{\circ} \mathrm{C}$ & $4^{\circ} \mathrm{C}$ & $25^{\circ} \mathrm{C}$ & $4^{\circ} \mathrm{C}$ & $25^{\circ} \mathrm{C}$ & $4^{\circ} \mathrm{C}$ & $25^{\circ} \mathrm{C}$ & $4^{\circ} \mathrm{C}$ & $25^{\circ} \mathrm{C}$ & $4^{\circ} \mathrm{C}$ & $25^{\circ} \mathrm{C}$ & $4^{\circ} \mathrm{C}$ \\
\hline $\mathrm{NaCl}$ & $14(1)$ & $11(1)$ & 2.79 & 2.11 & 5.57 & 4.23 & 2.79 & 2.11 & 2.79 & 2.11 & 0.90 & 0.93 \\
\hline $\mathrm{MgCl}_{2}$ & $11(1)$ & $10(2)$ & 1.30 & 1.17 & 3.89 & 3.50 & 2.60 & 2.33 & 3.89 & 3.50 & 0.92 & 0.93 \\
\hline $\mathrm{CaCl}_{2}$ & $8(1)$ & $10(1)$ & 0.78 & 1.00 & 2.35 & 3.00 & 1.57 & 2.00 & 2.35 & 3.00 & 0.96 & 0.95 \\
\hline $\mathrm{NaClO}_{4}$ & $12(1)$ & $7(2)$ & 1.11 & 0.61 & 2.23 & 1.23 & 1.11 & 0.61 & 1.11 & 0.61 & 0.96 & 0.98 \\
\hline $\mathrm{Mg}\left(\mathrm{ClO}_{4}\right)_{2}$ & $5(1)$ & $4(1)$ & 0.24 & 0.19 & 0.71 & 0.56 & 0.47 & 0.37 & 0.71 & 0.56 & 0.99 & 0.99 \\
\hline $\mathrm{Ca}\left(\mathrm{ClO}_{4}\right)_{2}$ & $3(1)$ & $3(1)$ & 0.13 & 0.13 & 0.39 & 0.39 & 0.26 & 0.26 & 0.39 & 0.39 & 0.99 & 0.99 \\
\hline
\end{tabular}

Values in parentheses give the deviation as described in Section 2.2.

*Water activity calculated from the Pitzer equation (Pitzer, 1991) with Pitzer parameters taken from Toner et al. (2015). The temperature dependence $\left(25^{\circ} \mathrm{C}\right.$ vs. $\left.4^{\circ} \mathrm{C}\right)$ of the water activity is negligible for $\mathrm{Cl}^{-}$(Fontan and Chirife, 1981) and $\mathrm{ClO}_{4}^{-}$solutions (Toner and Catling, 2016) at temperatures above $0^{\circ} \mathrm{C}$. 

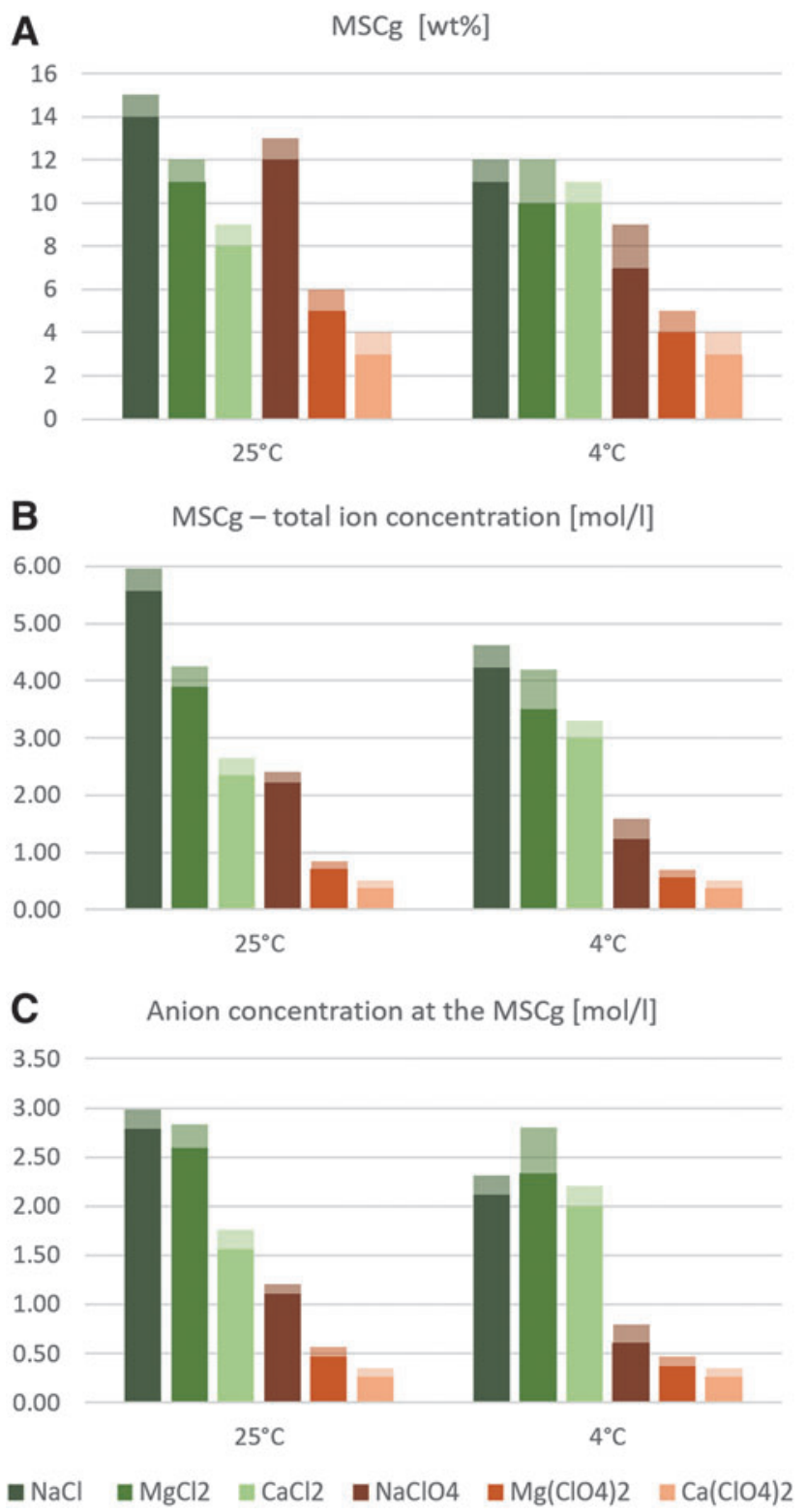

FIG. 2. Maximum salt concentrations suitable for growth (MSCg) of $P$. halocryophilus expressed as wt\% (A), and total molar concentration (sum of cation and anion concentration) (B), and the molar anion concentrations at the corresponding $\mathrm{MSCg}(\mathbf{C})$. Transparent parts of the bars represent the salinity range for which neither growth nor complete demise of the culture could be determined within the time of the experiment (see Section 2.2). The water activities and ionic strengths at the MSCg are shown in Fig. S13.

calcium $\left(\mathrm{Ca}^{2+}\right)$ tolerance of $P$. halocryophilus at lower temperatures.

In contrast, the sodium $\left(\mathrm{Na}^{+}\right)$tolerance is decreased at lower temperatures for both anions, $\mathrm{Cl}^{-}$and $\mathrm{ClO}_{4}^{-}$(Fig. 3). The tolerances to magnesium $\left(\mathrm{Mg}^{2+}\right)$ are only slightly reduced at $4^{\circ} \mathrm{C}\left(1 \mathrm{wt} \%\right.$ also for both anions, $\mathrm{Cl}^{-}$and $\left.\mathrm{ClO}_{4}{ }^{-}\right)$. The reduction in the $\mathrm{Na}^{+}$tolerance at $4^{\circ} \mathrm{C}$ on the one hand and the increased $\mathrm{Ca}^{2+}$ tolerance at $4^{\circ} \mathrm{C}$ on the other hand led to an equalization of the anion $\left(\mathrm{Cl}^{-}\right.$or $\left.\mathrm{ClO}_{4}{ }^{-}\right)$concentration at the MSCg at $4^{\circ} \mathrm{C}$, while at $25^{\circ} \mathrm{C}$ the differences between the anion concentrations for the three different cationic species $\left(\mathrm{Na}^{+}, \mathrm{Mg}^{2+}\right.$, and $\mathrm{Ca}^{2+}$ ) are more pronounced (Fig. 2).

\subsection{Cellular and colonial phenotypic salt-stress adaptations}

3.2.1. Colonial phenotypic adaptations. P. halocryophilus cells grown in liquid cultures exhibit with an increase in salt concentration, particularly for perchlorate salts, the tendency to develop macroscopic cohesive biofilms that could only be disrupted by intense shaking or vortexing (Fig. 4A).

Furthermore, it was observed that a novel colony phenotype (type II) appears only on plates inoculated with aliquots from cells grown in $\mathrm{ClO}_{4}{ }^{-}$-rich medium (especially with $>9 \mathrm{wt} \% \mathrm{NaClO}_{4}$ at $25^{\circ} \mathrm{C}$ ). This type II colony is paler and duller then the usual colonies (type I) that are shiny and orange (Fig. 4) and does not occur in cultures grown in saltfree or $\mathrm{Cl}^{-}$-containing media. Occasionally, both colony types occurred on plates inoculated with aliquots from cells grown in media with perchlorate concentrations of a few weight percent below the MSCg (Fig. 4B). Sporadically, such colonies underwent a transformation from the type II back to the type I after approximately 2 weeks of growth on the agar plates (Fig. 4C). Contamination was ruled out through $16 \mathrm{~S}$ sequencing of both colony types $(99.90 \%$ sequence similarity of type I versus type II, data not shown), suggesting that the colony type II represents a reversible multigenerational phenotypic adaptation of $P$. halocryophilus to high perchlorate salt stress. Type II colonies needed 3-5 times longer than type I colonies to reach comparable colony sizes.

Two additional colony phenotypes were observed on agar plates: Type III colonies are irregular jagged in shape and occurred on agar plates inoculated with magnesium-rich $\left(\mathrm{Cl}^{-}\right.$ and $\mathrm{ClO}_{4}^{-}$) cultures (Fig. S14). Type IV colonies are mucoidal and shiny, merge rapidly during growth, and occurred on agar plates inoculated with $\mathrm{CaCl}_{2}$-rich cultures (Fig. S15).

3.2.2. Cellular phenotypic adaptations. P. halocryophilus cells grown in liquid media containing no additional salts, seen under the light and fluorescence microscope as well as in SEM images, occur predominantly as single cells, diplococci, or small cell aggregates (Fig. 5A-5C) and have an overall smooth surface with nodules occurring largely along the cell division plane (Fig. 5B) as previously described (Mykytczuk et al., 2016).

Cells, however, grown in $\mathrm{Cl}^{-}$-rich media occur predominantly in larger clusters of $\sim 100$ cells (Fig. 5D-5F); moreover, cells grown in perchlorate-rich media cluster into even larger aggregates of $>1000$ cells (Fig. 5G-5I). These clusters, containing living and dead cells (Fig. 5G), are highly cohesive and could not be disrupted by $5 \mathrm{~min}$ of ultrasonication nor by washing with $100 \%$ ethanol and killing all cells (Fig. S16). The cell clustering predominantly occurring in perchlorate-rich media led to higher uncertainties and irregularities in the growth curves of these samples (e.g., Figs. S7 and S11). Concurrent with cell clustering under salt-stress conditions is the development of intercellular nanofilaments within a cluster (Fig. 5E). Additionally, cells in $\mathrm{CaCl}_{2}$-rich media developed surface encrustation (Fig. 5F). 


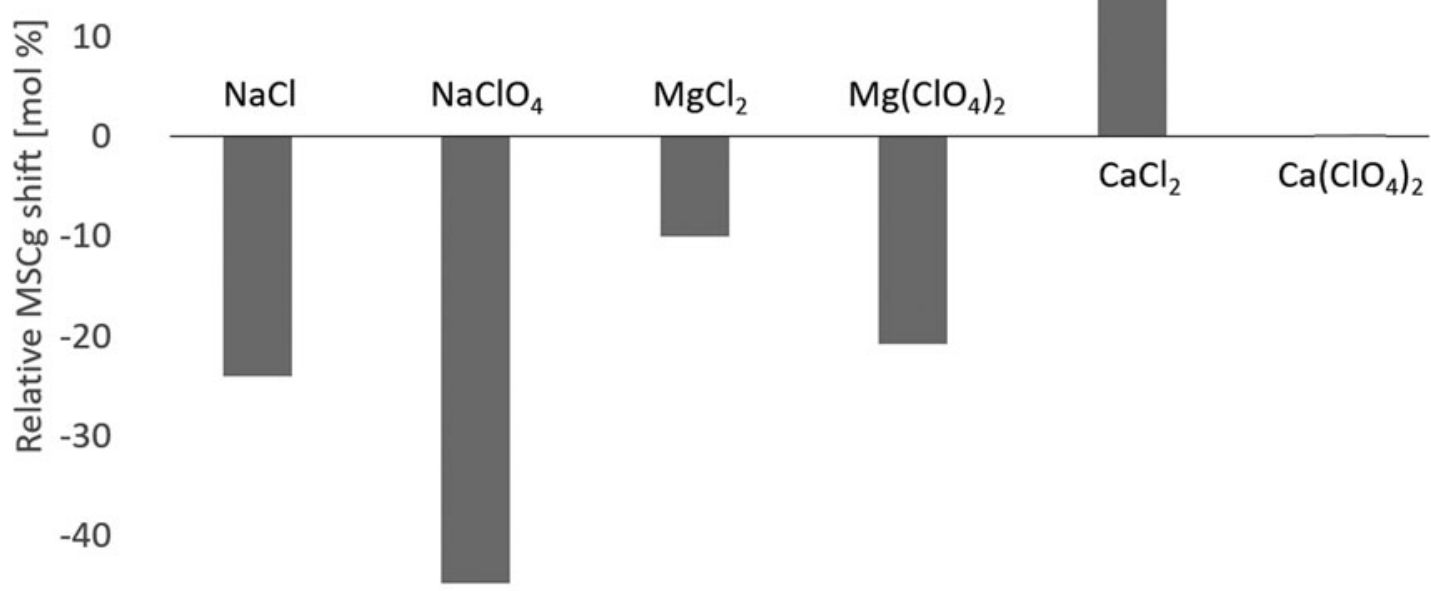

$-50$

FIG. 3. Relative changes in the MSCg induced by lowering the incubation temperature from $25^{\circ} \mathrm{C}$ to $4^{\circ} \mathrm{C}$.

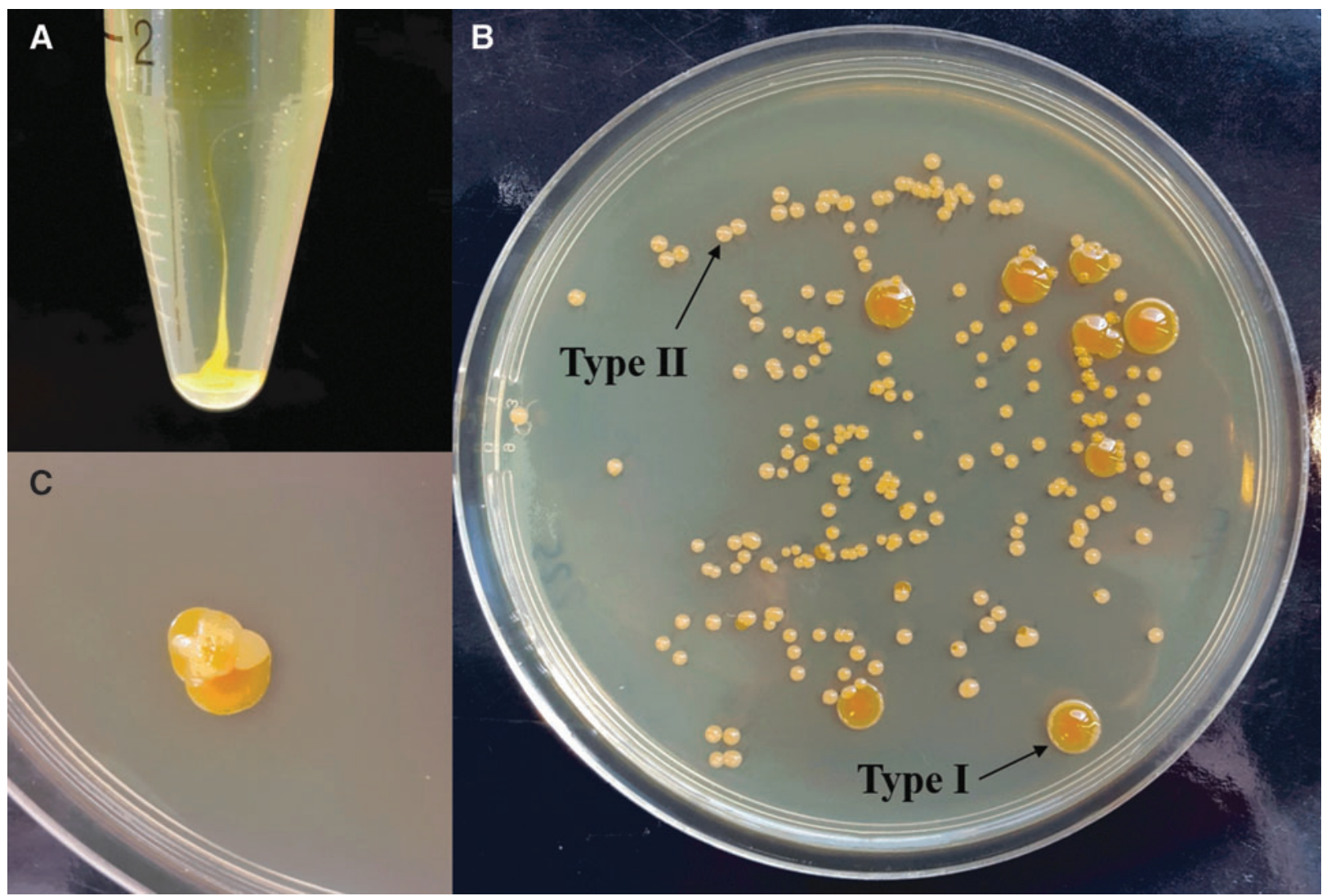

FIG. 4. Macroscopically visible salt stress responses: (A) Biofilm-like cell clumping occurring in a $10 \mathrm{wt} \% \mathrm{NaClO}_{4}$ culture after 1 month of growth. (B) Two different colony morphologies of $P$. halocryophilus observed 1 week after plating a $9 \mathrm{wt} \% \mathrm{NaClO}_{4}$ culture at $25^{\circ} \mathrm{C}$. The shiny intense-orange colonies (type I) represent the colony morphology typical for $P$. halocryophilus grown in medium with low salt concentrations. The paler and smaller colonies (type II) only occurred after plating perchlorate-rich cultures. (C) Transformation of a type II colony into type I after 2 weeks of colony growth. 

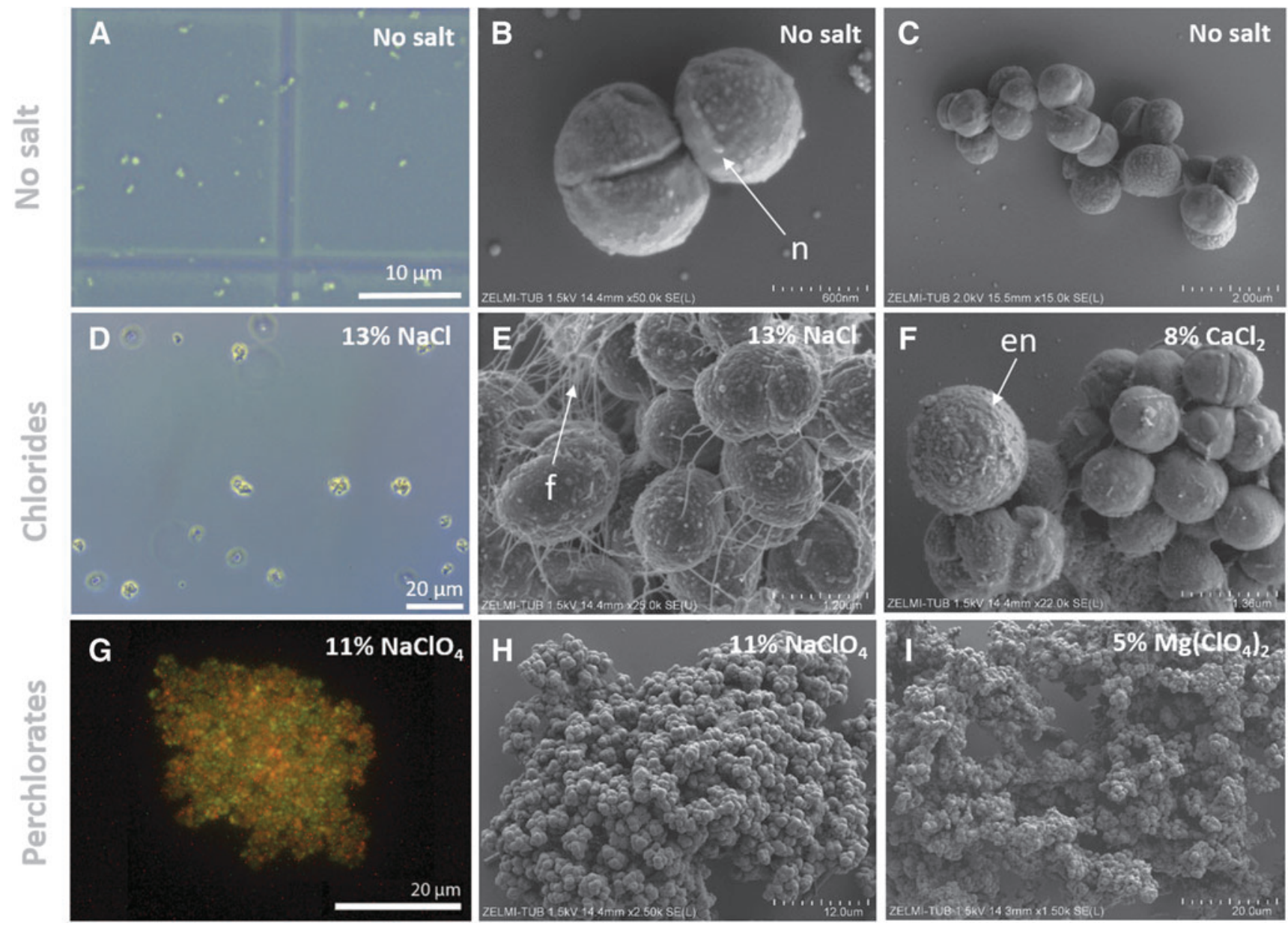

FIG. 5. Light microscopy (A, D), fluorescence microscopy (after live/dead staining) (G), and SEM (B-C, E-F, H-I) images of $P$. halocryophilus after growth in media containing no salts $(\mathbf{A}-\mathbf{C})$, chlorides $(\mathbf{D}-\mathbf{F})$, and perchlorates $(\mathbf{G}-\mathbf{I})$ at $25^{\circ} \mathrm{C}$. Cells grown in salt-free media developed smooth surfaces with some nodular features (n) and occurred as single cells, diplococci, or smaller cell aggregates (A-C). Several salt stress responses were observed including formation of cell clusters (G-I) and filaments (f) (E), and encrustation (en) of some cells in $\mathrm{CaCl}_{2}$-containing cultures (F).

\section{Discussion}

\subsection{Salt-stress response and phenotypic adaptation}

Microbial salt-stress responses and multigenerational adaptations such as microbial cell aggregation and biofilm formation have been observed for various stress conditions such as desiccation (Monier and Lindow, 2003), UV radiation (Fröls et al., 2008), or $\mathrm{NaCl}$ exposure (Philips et al., 2017). Thus far, $\mathrm{NaCl}$ is the only salt for which the salt-stress response of $P$. halocryophilus has been investigated, showing that the cells developed an EPS-like coating with short filament-like features if grown in $15 \mathrm{wt} \%(18 \mathrm{wt} / \mathrm{vol} \%) \mathrm{NaCl}$ media at $-5^{\circ} \mathrm{C}$ (see Fig. 1e, 1f in Mykytczuk et al., 2016).

For our experimental growth conditions, we show a similar trend for $P$. halocryophilus at high $\mathrm{NaCl}$ concentrations, where the cells developed even longer nanofilaments (Fig. 5E). The formation of similar nanofilaments linking cells within one cluster has also been observed previously, for example for the halophilic archaeon Halococcus salifodinae (see Fig. 2 in Legat et al., 2013). Furthermore, we conducted experiments with two additional $\mathrm{Cl}^{-}$and three $\mathrm{ClO}_{4}{ }^{-}$salts showing that $P$. halocryophilus develops particularly large and highly cohesive clusters especially if grown in perchlorate-rich media (Fig. 5G-5I). Previous studies on Hydrogenothermus marinus have shown a formation of cell chains under increased perchlorate concentrations which has been speculated to result from incomplete cell division (Beblo-Vranesevic et al., 2017), a physiological effect of perchlorate that could be similar for $P$. halocryophilus. Such a mechanism would be in accordance with our observation that cell clusters could neither be destroyed through ultrasonication nor through killing the cells with ethanol treatment (Fig. S16).

Furthermore, our results show the development of cohesive biofilms in perchlorate-rich media (Fig. 4A), and if transferred to agar plates, the occurrence of an additional colony morphology (type II, Fig. 4B). These are both macroscopic phenotypes consistent with the microscopic development of large cell clusters linked by numerous nanofilaments. Such stress-induced changes in colony morphology are also known for other stressors than high salinity; for example, under nutrient starvation Vibrio cholerae colonies change from the normal translucent to a rugose type (Wai et al., 1998), or with a $\mathrm{pH}$ shift Bacillus subtilis colonies change from the normal notched "volcano-like" to a round and front-elevated "craterlike" shape (Tasaki et al., 2017). 
The phenotypic responses described above demonstrate that organisms like $P$. halocryophilus can develop perchloratespecific stress adaptations that are not (or only to a lower extent) used to counteract high chloride concentrations. This is an important finding for all extraterrestrial environments with naturally occurring perchlorates. This might include not only Mars but any planetary bodies with a relatively dry surface (to avoid leaching of salts) and increased UV radiation (to oxidize chlorides [Carrier and Kounaves, 2015]). For example, spectral data indicate the presence of perchlorates at the surface of the icy moon Europa (Ligier et al., 2016), which could entail delivery of perchlorates to Europa's subsurface ocean (Hand et al., 2007). Also, based on the observed phenotypic adaptations of $P$. halocryophilus, microfossils of such organisms found in perchlorate-rich environments might be present in the form of cell clusters or biofilms rather than in the form of single cells.

\subsection{Halotolerances of P. halocryophilus at $25^{\circ} \mathrm{C}$ and $4^{\circ} \mathrm{C}$}

To our knowledge, the only $\mathrm{MSCg}$ data for P. halocryophilus have been reported for $\mathrm{NaCl}$ being $16 \mathrm{wt} \%$ $(19 \mathrm{wt} / \mathrm{vol} \%)$ at $25^{\circ} \mathrm{C}$ (Mykytczuk et al., 2012) and $15 \mathrm{wt} \%$ $(18 \mathrm{wt} / \mathrm{vol} \%)+7 \mathrm{wt} / \mathrm{vol} \%$ glycerol at $-15^{\circ} \mathrm{C}$ (Mykytczuk et al., 2013, 2016). In contrast, we found a lower $\mathrm{NaCl}$ halotolerance of 14 and $11 \mathrm{wt} \%$ at $25^{\circ} \mathrm{C}$ and $4{ }^{\circ} \mathrm{C}$, respectively, which can have various causes. For example: (1) Mutation of the lab culture and loss of part of its physiological abilities since isolation from its natural environment and first description (Mykytczuk et al., 2012). (2) Different, and commonly not or only partially reported, preconditioning and adaptation procedures for cell growth such as the increment size of salt increase, growth curve phase used for transfer inoculation, and transfer or culture volume and agitation. (3) Use of a different growth media: while we used DSMZ growth media \#92 containing TSB and yeast extract, Mykytczuk (2013 and 2016) used a growth media containing TSB and glycerol to maintain the medium liquid down to temperatures of $-15^{\circ} \mathrm{C}$. Glycerol is known to be an osmoprotectant and, thus, might have caused the elevated $\mathrm{NaCl}$ tolerance at low temperatures. Whether this difference in halotolerance would have also applied to other salts remains unknown, since no other salts than $\mathrm{NaCl}$ have been investigated for $P$. halocryophilus prior to this study.

The determination of MSCg values for multiple salts, as presented here for the first time for P. halocryophilus, provides the opportunity to test if any single physicochemical aspect of saline solutions is a limiting factor for growth. Our data, however, do not indicate that any individual factor (including total ion or anion concentration, ionic strength, water activity; see Table 1, Fig. 2, and Fig. S13) is responsible for the growth limitation of $P$. halocryophilus in saline solutions. Otherwise, the values of one of these physicochemical factors (e.g., water activity) would be similar for all salts, which is not the case.

However, our data indicate the following ion speciesdependent halotolerances for P. halocryophilus.

(1) The anion species, here $\mathrm{Cl}^{-}$versus $\mathrm{ClO}_{4}{ }^{-}$, plays the most dominant role determining the MSCg values independent of physicochemical unit, showing an overall at least 2.5fold higher tolerance to $\mathrm{Cl}^{-}$than to $\mathrm{ClO}_{4}^{-}$salts with the same cation. Nevertheless, the $\mathrm{MSCg}$ of $\mathrm{NaClO}_{4}$ $(12 \mathrm{wt} \% ; 1.1 \mathrm{M})$ is comparatively high and exceeds earlier findings for other organisms such as Haloferax mediterranei (0.6 M) (Oren et al., 2014), Halomonas venusta (1.0 M) (Al Soudi et al., 2017), Hydrogenothermus marinus (0.44 M) (Beblo-Vranesevic et al., 2017), different bacterial isolates from Big Soda Lake in Nevada, USA (0.17 M) (Matsubara et al., 2017), and Halorubrum lacusprofundi (0.8 M) (Laye and DasSarma, 2018). It should be noted that it is not clear how $P$. halocryophilus developed such high perchlorate tolerances. Perchlorates are rare in natural terrestrial environments and often coupled to the occurrences of nitrates, for example in the Atacama Desert, Chile (Dasgupta et al., 2005). No nitrates have been detected in the permafrost samples $P$. halocryophilus has been isolated from (Steven et al., 2007); thus it appears likely that this strain has never been exposed to environmental perchlorates and did not derive its resistance to perchlorate that way.

(2) The cation species plays a similar role for growth at $25^{\circ} \mathrm{C}$, where $\mathrm{Na}^{+}$is the most tolerated cation for each group of anions, that is, $\mathrm{NaCl}$ among the chlorides and $\mathrm{NaClO}_{4}$ among the perchlorates.

In summary, for growth at $25^{\circ} \mathrm{C}, \mathrm{Na}^{+}$and $\mathrm{Cl}^{-}$ions are individually the most tolerated ions, and $\mathrm{NaCl}$ is the salt to which $P$. halocryophilus has the highest halotolerance $(2.8 \mathrm{M})$ at the lowest water activity (0.90). Life on Earth has generally adapted most efficiently to the most abundant and/or common factors in nature; for salt, this is $\mathrm{NaCl}$. Hence, our data suggest that the limitation of growth for $P$. halocryophilus is to a large degree based on evolutionary adaptations to brine veins (most likely consisting of $\mathrm{NaCl}$ ) present in permafrost soil (Steven et al., 2007). Also, all members of the genus Planococcus are halotolerant and have been isolated predominantly from cold and/or saline environments like the Arctic, Antarctic, or marine habitats (Mykytczuk et al., 2012).

Perchlorate ions in aqueous solutions are relatively inert and non-oxidizing due to kinetic barriers (Urbansky, 1998) but rare in natural environments on Earth and therefore presumably exhibit an enhanced toxicity compared to chlorides. Thus, it seems plausible that putative martian microbes could adapt to naturally occurring perchlorate-rich environments to the same extent as Earth microbes such as Planococcus spp. did adapt to NaCl-enriched habitats. This idea is consistent with our finding that the tolerance to high salt concentrations can be increased through a stepwise inoculation toward higher concentrations. At low temperatures $\left(4^{\circ} \mathrm{C}\right.$ in this study) longer lag phases would provide even more time for adaption to higher salt concentrations to occur.

Additional to the ion species-dependent halotolerance, a temperature-dependent halotolerance of $P$. halocryophilus was observed, where at $25^{\circ} \mathrm{C}$ the MSCg values are different for each cation species, while at $4^{\circ} \mathrm{C}$ the cation species is less relevant and the MSCg values are more similar (Fig. 2). This MSCg value alignment at low temperatures appears to be largely caused by two separate trends.

(1) $\mathrm{Na}^{+}$-containing salts (i.e., $\mathrm{NaCl}$ and $\mathrm{NaClO}_{4}$ ) can be tolerated by $P$. halocryophilus to higher concentrations at higher temperatures. Possibly, the elaborate biochemical machinery evolved to cope with high $\mathrm{Na}^{+}$concentrations 
is kinetically more effective at optimal growth temperatures enhancing the overall halotolerance.

(2) In the case of $\mathrm{CaCl}_{2}$ we observe the opposite effect, where lowering the temperature increases the halotolerance to this salt. This observation is in accordance with a previous study showing that with decreasing temperature the survival of $P$. halocryophilus in eutectic $\mathrm{CaCl}_{2}$ brines is enhanced to a significantly larger degree than in $\mathrm{NaCl}, \mathrm{MgCl}_{2}$, or $\mathrm{NaClO}_{4}$ brines (Heinz et al., 2018). A low temperature-induced halotolerance enhancement has been described for example for the bacterial strain Clostridium sp. isolated from brine lenses in the Siberian permafrost (Gilichinsky et al., 2003) and for M. soligelidi (Morozova and Wagner, 2007) in NaCl-rich media. However, to our knowledge, $P$. halocryophilus is the first organism described thus far that shows an increased $\mathrm{CaCl}_{2}$ tolerance at lower temperatures and can grow at salt concentrations up to $10 \mathrm{wt} \%(1 \mathrm{M}) \mathrm{CaCl}_{2}$ at $4^{\circ} \mathrm{C}$ in the absence of kosmotropic ions which otherwise could compensate the chaotropic stress caused by calcium ions (Oren, 2013).

However, it remains unclear what mechanism causes the enhanced $\mathrm{CaCl}_{2}$ tolerance of $P$. halocryophilus at $4^{\circ} \mathrm{C}$, perhaps a psychrophilic optimization of the relevant biochemical machinery for coping with $\mathrm{Ca}^{2+}$ or simply the lethal effect of calcium being decreased at lower temperatures. It has been proposed that the increased $\mathrm{CaCl}_{2}$ tolerance at lower temperatures might be due to the formation of larger and more stable hydration shells around calcium ions with decreasing temperature (Heinz et al., 2018). A possible biological explanation is a beneficial effect caused by cellular encrustation, which was only observed in $\mathrm{CaCl}_{2}$-rich media in this study (Fig. 5F). Correspondingly, cellular encrustation containing $20 \%$ calcium carbonate has been documented previously for $P$. halocryophilus cells grown at subzero temperatures in NaCl-rich media (Mykytczuk et al., 2016). Similar encrustation might be triggered in the presence of high $\mathrm{Ca}^{2+}$ amounts and might provide an efficient calcium resistance strategy due to the microbial mediated calcium carbonate precipitation. This positive effect might be increased at lower temperatures.

Another factor that might play a role for the enhanced $\mathrm{Ca}^{2+}$ tolerance at lower temperatures is the chaotropicity of $\mathrm{Ca}^{2+}$. Chaotropic compounds increase the flexibility of macromolecules like proteins and, thus, can limit life at high temperatures (Hallsworth et al., 2007), but they can also benefit microbial growth at low temperatures (Chin et al., 2010; Rummel et al., 2014). Cray et al. (2013) found that the chaotropic activity for $\mathrm{CaCl}_{2}\left(92.2 \mathrm{~kJ} \mathrm{~kg}^{-1} \mathrm{~mol}^{-1}\right)$ is significantly higher than for $\mathrm{MgCl}_{2}\left(54.0 \mathrm{~kJ} \mathrm{~kg}^{-1} \mathrm{~mol}^{-1}\right)$ while $\mathrm{NaCl}$ is a kosmotropic compound $\left(-11.0 \mathrm{~kJ} \mathrm{~kg}^{-1}\right.$ $\mathrm{mol}^{-1}$ ). These data suggest that the high chaotropicity of $\mathrm{CaCl}_{2}$ (and potentially also of $\mathrm{Ca}\left(\mathrm{ClO}_{4}\right)_{2}$, but data for perchlorates are lacking) might contribute to the enhanced microbial $\mathrm{Ca}^{2+}$ tolerance at low temperatures.

Additional work is needed to better understand the observed general trends in the habitability of Mars-analog brines in dependence of the type of salt, its concentration, and temperature. Additional long-term studies under subzero temperatures, similar to martian environments, should be conducted, especially since studies have shown that $P$. halocryophilus is able to grow under these conditions (Mykytczuk et al., 2013,
2016). It is possible that lowering the experimental temperature to subzero values will further increase the tolerance of $P$. halocryophilus to $\mathrm{Ca}^{2+}$. We also recommend that other microbial strains (including anaerobic ones) or communities should be investigated under similar experimental conditions to widen our understanding of life in cold brines.

\section{Conclusion}

For the first time, this study provides insights into the extremotolerant bacterium $P$. halocryophilus, which is well known for its tolerance to both cold temperatures and high concentration of salts, on how it survives and adapts not only to $\mathrm{NaCl}$ solutions but all Mars-relevant $\mathrm{Cl}^{-}$and $\mathrm{ClO}_{4}{ }^{-}$ salt solutions at different temperatures. Although growth in highly concentrated eutectic brines is not possible (Heinz et al., 2018), the tolerance to the salts investigated in this study is intriguing and can even be enhanced by a stepwise increase in the salt concentration. For example, with $12 \mathrm{wt} \%(1.1 \mathrm{M}) \mathrm{NaClO}_{4}$ we found the highest bacterial tolerance to $\mathrm{ClO}_{4}{ }^{-}$reported to date. For $\mathrm{CaCl}_{2}$-containing cell cultures we could show that by lowering the temperature from $25^{\circ} \mathrm{C}$ to $4^{\circ} \mathrm{C}$ the halotolerance increases from $8 \mathrm{wt} \%(0.8 \mathrm{M})$ to $10 \mathrm{wt} \%(1.0 \mathrm{M})$, respectively, while tolerances to $\mathrm{Na}^{+}$and $\mathrm{Mg}^{2+}$ are decreased for the same temperature decline.

The increased $\mathrm{Ca}^{2+}$ tolerance at lower temperatures corresponds well to the previously described enhanced survival in low-temperature brines (Heinz et al., 2018) and plays an important role for the habitability of martian environments where $\mathrm{Ca}^{2+}$-rich brines might be present in the shallow subsurface (Burt, 2003). Furthermore, $\mathrm{Ca}^{2+}$ is thought to be the main counter ion in $\mathrm{ClO}_{4}^{-}$salts on Mars (Kounaves et al., 2014), and $\mathrm{Ca}\left(\mathrm{ClO}_{4}\right)_{2}$ might be a main component of the recently discovered subsurface lake near the martian south pole and could be responsible for its freezing point depression (Orosei et al., 2018).

Additionally, we described several salt adaption mechanisms like cell clustering, the formation of nanofilaments, encrustation of cells, and changes in the cell colony morphology. These data provide insight into how life could adapt to such high salt concentrations necessary for a sufficient freezing point depression allowing liquid water to be stable close to the martian surface.

\section{Acknowledgments}

This project was funded by European Research Council Advanced Grant "Habitability of Martian Environments" (HOME, no. 339231). All the numerical data for this paper are provided in the figures, tables, and supplementary information and are also available in tabular form from the authors upon request (schulze-makuch@tu-berlin.de). We would like express our thanks to two anonymous reviewers whose comments and suggestions helped improve this manuscript.

\section{Author Disclosure Statement}

No competing financial interests exist.

\section{References}

Al Soudi, A.F., Farhat, O., Chen, F., Clark, B.C., and Schneegurt, M.A. (2017) Bacterial growth tolerance to concentrations of 
chlorate and perchlorate salts relevant to Mars. Int J Astrobiol 16: 229-235.

Beblo-Vranesevic, K., Huber, H., and Rettberg, P. (2017) High tolerance of Hydrogenothermus marinus to sodium perchlorate. Front Microbiol 8, doi:10.3389/fmicb.2017.01369.

Burt, D.M. (2003) Electrically conducting, Ca-rich brines, rather than water, expected in the martian subsurface. $J$ Geophys Res 108, doi:10.1029/2002JE001862.

Carrier, B.L. and Kounaves, S.P. (2015) The origins of perchlorate in the martian soil. Geophys Res Lett 42:3739-3745.

Chin, J.P., Megaw, J., Magill, C.L., Nowotarski, K., Williams, J.P., Bhaganna, P., Linton, M., Patterson, M.F., Underwood, G.J.C., Mswaka, A.Y., and Hallsworth, J.E. (2010) Solutes determine the temperature windows for microbial survival and growth. Proc Natl Acad Sci USA 107:7835-7840.

Clifford, S.M., Lasue, J., Heggy, E., Boisson, J., McGovern, P., and Max, M.D. (2010) Depth of the martian cryosphere: revised estimates and implications for the existence and detection of subpermafrost groundwater. J Geophys Res 115, doi:10.1029/2009JE003462.

Cray, J.A., Russell, J.T., Timson, D.J., Singhal, R.S., and Hallsworth, J.E. (2013) A universal measure of chaotropicity and kosmotropicity. Environ Microbiol 15:287-296.

Dasgupta, P.K., Martinelango, P.K., Jackson, W.A., Anderson, T.A., Tian, K., Tock, R.W., and Rajagopalan, S. (2005) The origin of naturally occurring perchlorate: the role of atmospheric processes. Environ Sci Technol 39:1569-1575.

Davila, A.F. and Schulze-Makuch, D. (2016) The last possible outposts for life on Mars. Astrobiology 16:159-168.

Davila, A.F., Duport, L.G., Melchiorri, R., Jänchen, J., Valea, S., de los Rios, A., Fairén, A.G., Möhlmann, D., McKay, C.P., Ascaso, C., and Wierzchos, J. (2010) Hygroscopic salts and the potential for life on Mars. Astrobiology 10:617-628.

Dickson, J.L., Head, J.W., Levy, J.S., and Marchant, D.R. (2013) Don Juan Pond, Antarctica: near-surface $\mathrm{CaCl}_{2}$-brine feeding Earth's most saline lake and implications for Mars. Sci Rep 3, doi:10.1038/srep01166.

Fontan, C.F. and Chirife, J. (1981) The evaluation of water activity in aqueous solutions from freezing point depression. Int J Food Sci Technol 16:21-30.

Fröls, S., Ajon, M., Wagner, M., Teichmann, D., Zolghadr, B., Folea, M., Boekema, E.J., Driessen, A.J.M., Schleper, C., and Albers, S.-V. (2008) UV-inducible cellular aggregation of the hyperthermophilic archaeon Sulfolobus solfataricus is mediated by pili formation. Mol Microbiol 70:938-952.

Gilichinsky, D., Rivkina, E., Shcherbakova, V., Laurinavichuis, K., and Tiedje, J. (2003) Supercooled water brines within permafrost - an unknown ecological niche for microorganisms: a model for astrobiology. Astrobiology 3:331-341.

Gunde-Cimerman, N., Plemenitaš, A., and Oren, A. (2018) Strategies of adaptation of microorganisms of the three domains of life to high salt concentrations. FEMS Microbial Rev 42:353-375.

Hallsworth, J.E., Yakimov, M.M., Golyshin, P.N., Gillion, J.L.M., D’Auria, G., de Lima Alves, F., La Cono, V., Genovese, M., McKew, B.A., Hayes, S.L., Harris, G., Giuliano, L., Timmis, K.N., and McGenity, T.J. (2007) Limits of life in $\mathrm{MgCl}_{2}$-containing environments: chaotropicity defines the window. Environ Microbial 9:801-813.

Hand, K.P., Carlson, R.W., and Chyba, C.F. (2007) Energy, chemical disequilibrium, and geological constraints on Europa. Astrobiology 7:1006-1022.

Harri, A.-M., Genzer, M., Kemppinen, O., Gomez-Elvira, J., Haberle, R., Polkko, J., Savijärvi, H., Rennó, N., Rodriguez-
Manfredi, J.A., Schmidt, W., Richardson, M., Siili, T., Paton, M., La Torre-Juarez, M.D., Mäkinen, T., Newman, C., Rafkin, S., Mischna, M., Merikallio, S., Haukka, H., Martin-Torres, J., Komu, M., Zorzano, M.-P., Peinado, V., Vazquez, L., and Urqui, R. (2014) Mars Science Laboratory relative humidity observations: initial results. J Geophys Res Planets 119:2132-2147.

Hecht, M.H., Kounaves, S.P., Quinn, R.C., West, S.J., Young, S.M.M., Ming, D.W., Catling, D.C., Clark, B.C., Boynton, W.V., Hoffman, J., Deflores, L.P., Gospodinova, K., Kapit, J., and Smith, P.H. (2009) Detection of perchlorate and the soluble chemistry of martian soil at the Phoenix lander site. Science 325:64-67.

Heinz, J., Schulze-Makuch, D., and Kounaves, S.P. (2016) Deliquescence-induced wetting and RSL-like darkening of a Mars analogue soil containing various perchlorate and chloride salts. Geophys Res Lett 43:4880-4884.

Heinz, J., Schirmack, J., Airo, A., Kounaves, S.P., and SchulzeMakuch, D. (2018) Enhanced microbial survivability in subzero brines. Astrobiology 18:1171-1180.

Hennings, E., Heinz, J., Schmidt, H., and Voigt, W. (2013) Freezing and hydrate formation in aqueous sodium perchlorate solutions. Z Anorg Allg Chem 639:922-927.

Kounaves, S.P., Chaniotakis, N.A., Chevrier, V.F., Carrier, B.L., Folds, K.E., Hansen, V.M., McElhoney, K.M., O'Neil, G.D., and Weber, A.W. (2014) Identification of the perchlorate parent salts at the Phoenix Mars landing site and possible implications. Icarus 232:226-231.

Laye, V.J. and DasSarma, S. (2018) An Antarctic extreme halophile and its polyextremophilic enzyme: effects of perchlorate salts. Astrobiology 18:412-418.

Legat, A., Denner, E.B.M., Dornmayr-Pfaffenhuemer, M., Pfeiffer, P., Knopf, B., Claus, H., Gruber, C., König, H., Wanner, G., and Stan-Lotter, H. (2013) Properties of $\mathrm{Ha}$ lococcus salifodinae, an isolate from Permian rock salt deposits, compared with halococci from surface waters. Life 3: 244-259.

Ligier, N., Poulet, F., Carter, J., Brunetto, R., and Gourgeot, F. (2016) Vlt/sinfoni observations of Europa: new insights into the surface composition. Astron J 151, doi:10.3847/00046256/151/6/163.

Martínez, G.M. and Renno, N.O. (2013) Water and brines on Mars: current evidence and implications for MSL. Space Sci Rev 175:29-51.

Matsubara, T., Fujishima, K., Saltikov, C.W., Nakamura, S., and Rothschild, L.J. (2017) Earth analogues for past and future life on Mars: isolation of perchlorate resistant halophiles from Big Soda Lake. Int J Astrobiol 16:218228.

Monier, J.-M. and Lindow, S.E. (2003) Differential survival of solitary and aggregated bacterial cells promotes aggregate formation on leaf surfaces. Proc Natl Acad Sci USA 100: 15977-15982.

Morozova, D. and Wagner, D. (2007) Stress response of methanogenic archaea from Siberian permafrost compared with methanogens from nonpermafrost habitats. FEMS Microbiol Ecol 61:16-25.

Mykytczuk, N.C.S., Wilhelm, R.C., and Whyte, L.G. (2012) Planococcus halocryophilus sp. nov., an extreme sub-zero species from high Arctic permafrost. Int J Syst Evol Microbiol 62:1937-1944.

Mykytczuk, N.C.S., Foote, S.J., Omelon, C.R., Southam, G., Greer, C.W., and Whyte, L.G. (2013) Bacterial growth at $-15^{\circ} \mathrm{C}$; molecular insights from the permafrost bacterium Planococcus halocryophilus Or1. ISME J 7:1211-1226. 
Mykytczuk, N.C.S., Lawrence, J.R., Omelon, C.R., Southam, G., and Whyte, L.G. (2016) Microscopic characterization of the bacterial cell envelope of Planococcus halocryophilus Or1 during subzero growth at $-15^{\circ} \mathrm{C}$. Polar Biol 39:701-712.

Nikolakakos, G. and Whiteway, J.A. (2015) Laboratory investigation of perchlorate deliquescence at the surface of Mars with a Raman scattering lidar. Geophys Res Lett 42:7899-7906.

Ojha, L., Wilhelm, M.B., Murchie, S.L., McEwen, A.S., Wray, J.J., Hanley, J., Massé, M., and Chojnacki, M. (2015) Spectral evidence for hydrated salts in recurring slope lineae on Mars. Nat Geosci 8:829-832.

Oren, A. (2013) Life in magnesium- and calcium-rich hypersaline environments: salt stress by chaotropic ions. In Polyextremophiles: Life under Multiple Forms of Stress. Cellular Origin, Life in Extreme Habitats and Astrobiology, edited by J. Seckbach, A. Oren, and H. Stan-Lotter, Springer Science and Business Media, Dordrecht, the Netherlands, pp 217232.

Oren, A., Elevi Bardavid, R., and Mana, L. (2014) Perchlorate and halophilic prokaryotes: implications for possible halophilic life on Mars. Extremophiles 18:75-80.

Orosei, R., Lauro, S.E., Pettinelli, E., Cicchetti, A., Coradini, M., Cosciotti, B., Di Paolo, F., Flamini, E., Mattei, E., Pajola, M., Soldovieri, F., Cartacci, M., Cassenti, F., Frigeri, A., Giuppi, S., Martufi, R., Masdea, A., Mitri, G., Nenna, C., Noschese, R., Restano, M., and Seu, R. (2018) Radar evidence of subglacial liquid water on Mars. Science 361:490-493.

Philips, J., Rabaey, K., Lovley, D.R., and Vargas, M. (2017) Biofilm formation by Clostridium ljungdahlii is induced by sodium chloride stress: experimental evaluation and transcriptome analysis. PloS One 12, doi:10.1371/journal.pone.0170406.

Pitzer, K.S. (1991) Activity Coefficients in Electrolyte Solutions, CRC Press, Boca Raton, FL.

Pontefract, A., Zhu, T.F., Walker, V.K., Hepburn, H., Lui, C., Zuber, M.T., Ruvkun, G., and Carr, C.E. (2017) Microbial diversity in a hypersaline sulfate lake: a terrestrial analog of ancient Mars. Front Microbiol 8, doi:10.3389/fmicb.2017.01819.

Raymond-Bouchard, I., Chourey, K., Altshuler, I., Iyer, R., Hettich, R.L., and Whyte, L.G. (2017) Mechanisms of subzero growth in the cryophile Planococcus halocryophilus determined through proteomic analysis. Environ Microbiol 19:4460-4479.

Ronholm, J., Raymond-Bouchard, I., Creskey, M., Cyr, T., Cloutis, E.A., and Whyte, L.G. (2015) Characterizing the surface-exposed proteome of Planococcus halocryophilus during cryophilic growth. Extremophiles 19:619-629.

Rummel, J.D., Beaty, D.W., Jones, M.A., Bakermans, C., Barlow, N.G., Boston, P.J., Chevrier, V.F., Clark, B.C., de Vera, J.-P.P., Gough, R.V., Hallsworth, J.E., Head, J.W., Hipkin, V.J., Kieft, T.L., McEwen, A.S., Mellon, M.T., Mikucki, J.A., Nicholson, W.L., Omelon, C.R., Peterson, R., Roden, E.E., Sherwood Lollar, B., Tanaka, K.L., Viola, D., and Wray, J.J. (2014) A new analysis of Mars "Special Regions": findings of the second MEPAG Special Regions Science Analysis Group (SR-SAG2). Astrobiology 14:887-968.

Schulze-Makuch, D., Schulze-Makuch, A., and Houtkooper, J.M. (2015) The physical, chemical and physiological limits of life. Life 5:1472-1486.

Schulze-Makuch, D., Airo, A., and Schirmack, J. (2017) The adaptability of life on Earth and the diversity of planetary habitats. Front Microbiol 8, doi:10.3389/fmicb.2017.02011.
Stamenković, V., Ward, L.M., Mischna, M., and Fischer, W.W. (2018) $\mathrm{O}_{2}$ solubility in martian near-surface environments and implications for aerobic life. Nat Geosci 11:905-909.

Steven, B., Briggs, G., McKay, C.P., Pollard, W.H., Greer, C.W., and Whyte, L.G. (2007) Characterization of the microbial diversity in a permafrost sample from the Canadian high Arctic using culture-dependent and culture-independent methods. FEMS Microbial Ecol 59:513-523.

Stratford, M. (1989) Yeast flocculation: calcium specificity. Yeast 5:487-496.

Tasaki, S., Nakayama, M., and Shoji, W. (2017) Selforganization of bacterial communities against environmental $\mathrm{pH}$ variation: controlled chemotactic motility arranges cell population structures in biofilms. PloS One 12, doi:10.1371/ journal.pone.0173195.

Toner, J.D. and Catling, D.C. (2016) Water activities of $\mathrm{NaClO}_{4}$ $\mathrm{Ca}\left(\mathrm{ClO}_{4}\right)_{2}$ and $\mathrm{Mg}\left(\mathrm{ClO}_{4}\right)_{2}$ brines from experimental heat capacities: water activity $>0.6$ below $200 \mathrm{~K}$. Geochim Cosmochim Acta 181:164-174.

Toner, J.D., Catling, D.C., and Light, B. (2015) Modeling salt precipitation from brines on Mars: evaporation versus freezing origin for soil salts. Icarus 250:451-461.

Urbansky, E.T. (1998) Perchlorate chemistry: implications for analysis and remediation. Bioremediat J 2:81-95.

Wai, S.N., Mizunoe, Y., Takade, A., Kawabata, S.I., and Yoshida, S.I. (1998) Vibrio cholerae O1 strain TSI-4 produces the exopolysaccharide materials that determine colony morphology, stress resistance, and biofilm formation. Appl Environ Microbiol 64:3648-3655.

Address correspondence to: Dirk Schulze-Makuch Center of Astronomy and Astrophysics Astrobiology Research Group Technical University of Berlin Hardenbergstr. 36 10623 Berlin Germany

E-mail: schulze-makuch@tu-berlin.de

Submitted 15 March 2019 Accepted 26 June 2019

$\quad$ Abbreviations Used
$\mathrm{CFU}=$ colony-forming unit
$\mathrm{DRH}=$ deliquescence relative humidity
$\mathrm{DSMZ}=$ German Collection of Microorganisms
$\quad$ and Cell Cultures
$\mathrm{EPS}=$ extracellular polymeric substance
$\mathrm{IM}=$ inoculation method
$\mathrm{MSCg}=$ maximum salt concentration suitable
$\mathrm{for}$ growth
$\mathrm{PB}=$ phosphate buffer
$\mathrm{PBS}=$ phosphate-buffered saline
$\mathrm{RH}=$ relative humidity
$\mathrm{SEM}=$ scanning electron microscopy
$\mathrm{TSB}=$ Tryptic soy broth

